\title{
The International Transmission of Monetary Policy in a Dollar Pricing Model
}

\author{
Juha Tervala \\ University of Helsinki and HECER
}

Discussion Paper No. 180

August 2007

ISSN 1795-0562

HECER - Helsinki Center of Economic Research, P.O. Box 17 (Arkadiankatu 7), FI-00014 University of Helsinki, FINLAND, Tel +358-9-191-28780, Fax +358-9-191-28781, E-mail info-hecer@helsinki.fi, Internet www.hecer.fi 


\title{
The International Transmission of Monetary Policy in a Dollar Pricing Model*
}

\begin{abstract}
This paper analyses the international transmission of monetary policy in the case where all export prices are set in US dollars. "Dollar pricing" implies that the international effects of US monetary shocks are different to those of European shocks because of asymmetric exchange rate pass-through to import prices. A dollar pricing model can explain the observed asymmetry in the transmission of monetary policy: US monetary policy affects US output more than European monetary policy affects European output. I also show that US (European) shocks generate positive (negative) co-movements of consumption across countries. The paper concludes that under dollar pricing a monetary expansion is a beggar-thy-neighbour policy.
\end{abstract}

JEL Classification: F41, F42, F30

Keywords: Open economy macroeconomics, monetary policy, international policy transmission

Juha Tervala

Department of Economics

University of Helsinki

P.O. Box 17 (Arkadiankatu 7)

FI-00014 University of Helsinki

FINLAND

e-mail: juha.tervala@helsinki.fi

* Financial support from the Yrjö Jahnsson Foundation is gratefully acknowledged. I am grateful to Vesa Kanniainen, Mika Kortelainen, Anne Mikkola, Tapio Palokangas,Jouko Vilmunen, two anonymous referees and seminar participants at the University of Helsinki and HECER for comments. 


\section{Introduction}

A topic that has received considerable attention in new open economy macroeconomics (NOEM $)^{1}$ is the international transmission of monetary policy. The NOEM literature has shown that the transmission of monetary shocks across countries is predicated by the currency denomination of international trade. Most of the contributions that address the international transmission of monetary shocks, including the seminal Redux model of Obstfeld and Rogoff $(1995,1996)$, assume that export prices are set in the producer's currency. The literature refers to this case as "producer currency pricing" (PCP). In this case, there is complete pass-through of exchange rate changes to import prices.

Among others, Betts and Devereux $(2000,2001)$ have assumed that firms can price discriminate across countries and export prices can be set in the consumers' currency. This case is referred to as "local currency pricing" (LCP) or "pricing-to-market" (PTM). I use the former term. In this case, exchange rate pass-through to import prices is zero. ${ }^{2}$ In Betts and Devereux (2000), the authors incorporate LCP into the Obstfeld-Rogoff (1995) model. The authors show that the degree of short-run exchange rate pass-through is crucial for the international transmission of monetary shocks. For example, in the case of LCP (PCP) monetary shocks generate high positive (negative) co-movement of output across countries and large negative (positive) co-movement of consumption. In addition, in the case of PCP a domestic monetary shock unambiguously raises both domestic and foreign welfare (Obstfeld and Rogoff 1995, 1996) whereas in the case of LCP a domestic monetary shock reduces foreign welfare (Betts and Devereux 2000).

One limitation of the recent literature is that it has focused primarily on the case where exchange rate pass-through is symmetric, i.e. the same for both countries. A third possibility, that all export prices are set in one currency, has received less attention despite it being "probably the most relevant from an empirical viewpoint" (Corsetti - Pesenti 2005, 22). I refer to this case as "dollar pricing" (DP). In the DP case, exchange rate passthrough is asymmetric. If all firms set export prices in the home country's currency, exchange rate pass-through is zero in the home country and one in the foreign country. The assumption of asymmetric export pricing seems

\footnotetext{
${ }^{1}$ Lane (2001) provides an extensive survey of the NOEM literature. Lane and Ganelli (2003) focus on the exchange rate pass-though debate and the role of the current account and net foreign assets in adjustment dynamics.

${ }^{2}$ Engel (2002), Obstfeld (2002) and Obstfeld and Rogoff (2000) discuss how low passthrough of exchange rate changes to consumer prices affect the expenditure switching effect of a nominal exchange rate change.
} 
to be important in the light of the results of Schmidt (2006). The empirical literature on the international effects of monetary shocks shows that US monetary shocks increase both US and "foreign" (typically non-US G7) consumption and output (see e.g. Holman and Neumann 2002). This evidence is not easily reconciled with symmetric pricing (PCP/LCP). Schmidt (2006) shows that under DP a monetary shock increases both domestic and foreign output and consumption.

The main purpose of this paper is to analyse the international transmission of monetary shocks in the DP case. This includes carrying out an analysis of the welfare effects of monetary shocks. To address these issues, I develop a standard two-country NOEM model that is based on Betts and Devereux (2000). I extend the Betts-Devereux model in two ways. The main extension is the introduction of asymmetric price setting (i.e. dollar pricing). Betts and Devereux (2000) assume that the same fraction of firms in each country set prices in the consumers' currency. I instead assume that the fraction of LCP can be different across countries. Second, I introduce a Calvo-type staggered price setting. The assumption of staggered price setting, as opposed to the hypothesis of simultaneous one-step-ahead pricing, allows for richer dynamics in the responses to monetary shocks.

As mentioned, there is a substantial literature on the international effects of monetary shocks. These papers, among others, include Sutherland (1996), Pierdzioch (2003) and Schmidt (2006). All of these papers develop a NOEM model that makes use of a staggered price setting and numerical simulations. The present model is in one special case, where all export prices are set in the producer's currency, almost identical to the model of Sutherland (1996). On the other hand, in the other special case, where all export prices are set in the consumer's currency, the model is identical to Pierdzioch (2003). A limitation of these papers is that only the positive effects of monetary shocks are analysed. I also study the normative (welfare) effects of monetary shocks. The international transmission of monetary shocks in the case where exchange rate pass-through is asymmetric is analysed by Schmidt (2006). ${ }^{3}$ Schmidt (2006) extends the basic NOEM framework in several directions while I retain the basic framework so that the results of this model are easy to compare with those in the preceding literature. ${ }^{4}$ In addition, a limitation

\footnotetext{
${ }^{3}$ The assumption of dollar pricing is also used in the papers by Devereux et al. (2003), Devereux et al. (2007) and Corsetti and Pesenti (2005). These papers, however, do not address the topic of this paper.

${ }^{4}$ In this paper, in contrast to Schmidt (2006), there is no home bias in consumption, I abstract capital formation, there is only one international traded asset and the elasticity of substitution between goods produced in the same country is the same as the elasticity of substitution between goods produced in different countries.
} 
of Schmidt's (2006) paper is that only the effects of domestic monetary shocks are analysed. I analyse the effects of both domestic and foreign monetary shocks.

One of the main findings of this paper is that a DP model can explain the observed asymmetry in the transmission of monetary policy: domestic (US) monetary policy affects domestic (US) output more than foreign (European) monetary policy affects foreign (European) output. I show that under DP a domestic monetary shock increases domestic output and consumption more than a foreign shock increases foreign output and consumption. This implies that DP can explain the asymmetry in the transmission of monetary policy. Angeloni et al. (2003) find that a one percentage point increase in the US short-term interest rate has a substantially stronger negative effect on US output than a one percentage point increase in the Eurozone's interest rate has on the Eurozone's output. This implies that US monetary policy is more effective than Eurozone's monetary policy in terms of influencing the country's own output. In this paper, I demonstrate that asymmetric exchange rate pass-through can explain the relative ineffectiveness of monetary policy in the Eurozone.

As mentioned, Schmidt (2006) demonstrates that DP can imply that a domestic monetary shock increases both domestic and foreign output and consumption, consistent with empirical evidence. In this paper, I present results that call into question the robustness of Schmidt's (2006) results. I show that under DP a domestic monetary shock generates a positive effect on foreign output if the expenditure switching effect is weak i.e. the elasticity of substitution between domestic and foreign goods is sufficiently low and/or prices are sufficiently sticky. For example, if the elasticity of substitution between domestic and foreign goods is high, the international transmission of domestic shocks under DP appear to be similar to PCP i.e. domestic monetary shocks generate high positive co-movements of consumption across countries and negative co-movements of output across countries.

The model also offers important insights into the welfare effects of monetary policy under PCP. The introduction of staggered pricing into a standard NOEM model does not change any of the main results of Obstfeld and Rogoff (1995, 1996). As mentioned, one of the striking results of Obstfeld and Rogoff $(1995,1996)$ is that a monetary shock under PCP raises both domestic and foreign overall welfare by equal amounts. I show, however, that a monetary shock is a "beggar thyself" policy that substantially reduces domestic welfare and increases foreign welfare in the short run. This is because a monetary shock causes an increase in domestic output without an equivalent increase in consumption due to a deterioration in the terms of trade and the accumulation of net external assets. This implies that even though the terms of 
trade and current account effects do not affect overall welfare under PCP, they still have important implications for welfare dynamics. In the long run, a monetary shock increases domestic welfare and reduces foreign welfare.

Finally, I demonstrate that DP has important implications for welfare. In the short run, the welfare effects of a monetary shock under DP appear to be more similar to PCP than LCP: a monetary shock reduces domestic welfare but increases foreign welfare. The DP case reintroduces the current account as an important channel through which monetary policy affects welfare in the short run. A monetary shock reduces welfare, notwithstanding the improvement in the terms of trade. The current account effect dominates the terms of trade effect to an extent that the increase in consumption is much smaller than the increase in output in the first period after the shock. Therefore, domestic welfare is reduced in the short run. In the long run, a monetary shock raises domestic welfare but reduces foreign welfare. As in Schmidt (2006), the discounted present value of the change in utility is more similar to LCP than PCP: a monetary expansion under DP is a beggar-thy-neighbour policy.

The rest of the paper is structured as follows. Section 2 introduces the model and derives the equilibrium conditions. Section 2 presents and discusses the international transmission of monetary shocks, using illustrative numerical calculations. Section 3 concluded the paper.

\section{The Model}

\subsection{Country Size and Market Structure}

The world economy consists of two countries, home and foreign. ${ }^{5}$ For concreteness, the home country is referred to as the "US" and the foreign country as "Europe". There is a continuum of firms and households that are indexed by $z \in[0,1]$. A fraction $n$ of households and firms are located in the US while the fraction $1-n$ are located in Europe. Each firm produces a differentiated good, however, there are two types of firms. A fraction of firms in each country can "price-to-market". These firms set their prices in the currency of the buyer. I refer to these firms as LCP firms. In the US (Europe) the fraction of LCP firms is $b\left(b^{*}\right)$. The rest of firms set a unified price across the countries. These firms set their prices in the currency of the producer and I refer to these firms as PCP firms. These firms let prices abroad move one-to-one with the exchange rate.

Three special cases are worth observing. First, when $b=b^{*}=0$, all export prices are set in the producer's currency - the PCP case. Second, in

\footnotetext{
${ }^{5}$ As mentioned in the Introduction, the model is based on Betts and Devereux (2000).
} 
the LCP case: $b=b^{*}=1$. Third, when $b=0$ and $b^{*}=1$, all export prices are set in US dollars. As mentioned in the introduction, I refer to this case as dollar pricing.

Empirical evidence provides support for the asymmetry in price setting. A report by ECU institute (1995) summarizes that the national currency is the principal currency used for the denomination of national exports. However, the US is an exception, with $92 \%$ of exports and $80 \%$ of imports invoiced in US dollars (ECU institute 1995). Tavlas (1997) finds that 98\% of US exports and $89 \%$ of US imports were invoiced in dollars in 1992-1996. Tille and Goldberg (2005) find that $95 \%$ of US exports and $85 \%$ of US imports were invoiced in dollars in 2003. Thus "there is asymmetry such that U.S. exports to Europe are heavily invoiced in dollars, but European exports to the U.S. are also invoiced in dollars" (Devereux et al. 2003, 224). Hence, it is essential to study the international transmission of monetary shocks in the case where all export prices are set in one currency.

\subsection{Households}

\subsubsection{Preferences}

All households have identical preferences. The utility function of the representative US household is given by ${ }^{6}$

$$
U_{t}(z)=\sum_{s=t}^{\infty} \beta^{s-t}\left[\log C_{s}+\frac{\chi}{1-\varepsilon}\left(\frac{M_{s}}{P_{s}}\right)^{1-\varepsilon}-\frac{\ell_{s}(z)^{2}}{2}\right] .
$$

Here $\beta$ is the discount factor, $C$ is a consumption index (defined below), $\varepsilon$ and $\chi$ are positive parameters, $M$ is the nominal balances and $P$ is the consumer price index (defined below). The variable $\ell$ is the household's supply of labour. The consumption index is

$$
C=\left[\int_{0}^{1} c(z)^{\frac{\theta-1}{\theta}} d z\right]^{\frac{\theta}{\theta-1}}
$$

where $c(z)$ is consumption of good $z$ and $\theta>1$ measures the elasticity of substitution between differentiated goods. The consumer price index is

$P_{t}=\left[\int_{0}^{n} p_{t}(z)^{1-\theta} d z+\int_{n}^{n+(1-n) b^{*}} p_{t}\left(z^{*}\right)^{1-\theta} d z+\int_{n+(1-n) b^{*}}^{1}\left(E_{t} q_{t}\left(z^{*}\right)\right)^{1-\theta} d z\right]^{\frac{1}{1-\theta}}$.

\footnotetext{
${ }^{6}$ In the presentation of the model that follows, the equations for the foreign country are identical to those of the home country unless they are explicitly discussed.
} 
Prices $p$ represent dollar prices, prices $q$ represent euro prices and $E$ is the exchange rate (the dollar price of the euro). In general, European variables are indicated by asterisks but in the context of goods prices an asterisk means a price set by European firm $z^{*}$. Hence, $p_{t}(z)$ is the dollar price of a US good, $p_{t}\left(z^{*}\right)$ is the dollar price of European good $z^{*}$ and $q_{t}\left(z^{*}\right)$ is the euro price of a European good. Similarly, the European price index is

$$
P_{t}^{*}=\left[\int_{0}^{n(1-b)}\left(p_{t}(z) / E_{t}\right)^{1-\theta} d z+\int_{n(1-b)}^{n} q_{t}(z)^{1-\theta} d z+\int_{n}^{1} q_{t}\left(z^{*}\right)^{1-\theta} d z\right]^{\frac{1}{1-\theta}}
$$

\subsubsection{Budget Constraints and First-Order Conditions}

Households receive a wage income, dividends from firms and transfers from the government (seigniorage revenues). Households use income to purchase consumption goods and to accumulate money and a nominal bond. Households can hold two assets, national money and international assets. I assume that the only internationally traded asset is a riskless nominal bond, denominated in dollars. The budget constraint of the representative US household is

$$
M_{t}+\delta_{t} D_{t}=D_{t-1}+M_{t-1}+w_{t} \ell_{t}-P_{t} C_{t}+\pi_{t}+P_{t} \tau_{t} .
$$

Here $\delta_{t}$ is the dollar price of the bond $\left(\delta_{t}=\left(1+i_{t}\right)^{-1}\right.$, where $i_{t}$ is the US nominal interest rate) that pays one dollar in period $t+1, D_{t}$ denotes bonds held by the household at the beginning of period $t, w$ is the nominal wage paid to the household in a competitive labour market and $\pi$ denotes the nominal profits (dividends) of US firms. Each US household owns an equal share of all US firms. The government repays all seigniorage revenues to households in the form of lump-sum transfers.

Since bonds are denominated in dollars, the budget constraint of European households is

$$
M_{t}^{*}+\delta_{t}^{*} \frac{D_{t}^{*}}{E_{t}}=\frac{D_{t-1}^{*}}{E_{t}}+M_{t-1}^{*}+w_{t}^{*} \ell_{t}^{*}-P_{t}^{*} C_{t}^{*}+\pi_{t}^{*}+P_{t}^{*} \tau_{t}^{*},
$$

The European nominal interest rate is determined by uncovered interest parity

$$
(1+i)=\left(1+i^{*}\right) \frac{E_{t+1}}{E_{t}} .
$$

This implies that the realized return in dollars on the international bond at the beginning of period $t$ is $\left(1+i_{t}\right) E_{t-1} / E_{t}$. The global asset-market-clearing condition requires $n D_{t}+(1-n) D_{t}^{*}=0$. 
The first-order conditions for the maximization problems for US and European households are ${ }^{7}$

$$
\begin{gathered}
\delta_{t} P_{t+1} C_{t+1}=\beta P_{t} C_{t}, \\
\delta_{t}^{*} P_{t+1}^{*} C_{t+1}^{*} E_{t+1}=\beta P_{t}^{*} C_{t}^{*} E_{t}, \\
\ell_{t}=\frac{w_{t}}{C_{t} P_{t}} \\
\ell_{t}^{*}=\frac{w_{t}^{*}}{C_{t}^{*} P_{t}^{*}}, \\
\frac{M_{t}}{P_{t}}=\left(\frac{\chi C_{t}}{1-\delta_{t}}\right)^{\frac{1}{\varepsilon}}, \\
\frac{M_{t}^{*}}{P_{t}^{*}}=\left(\frac{\chi C_{t}^{*}}{1-\frac{\delta_{t}^{*} E_{t+1}}{E_{t}}}\right)^{\frac{1}{\varepsilon}} .
\end{gathered}
$$

Equations (4) and (5) are the Euler equations for optimal US and European consumption, respectively. Equations (6) and (7) govern the optimal labour supply. Households equate the marginal disutility of supplying an extra unit of labour with the marginal utility of extra private consumption that can that the extra labour supply brings. Equations (8) and (9) show that the demand for money is an increasing function of consumption and a decreasing function of the interest rate.

\subsection{Monetary Policy}

I abstract from government spending so the transfers to households are given by

$$
\tau_{t}=\frac{M_{t}-M_{t-1}}{P_{t}} .
$$

The money supply is assumed to follow a first-order autoregressive process described by the following equation

$$
\hat{M}_{t}=\rho \hat{M}_{t-1}+\epsilon_{M, t}
$$

where percentage changes from the baseline are denoted by hats and $\epsilon_{M, t}$ is an unpredictable shift in the money supply. I use the Dornbusch (1976) experiment of an unanticipated permanent rise in the money supply, assuming $\rho=1$.

\footnotetext{
${ }^{7}$ Since the model hitherto is identical to that of Betts and Devereux (2000), the first order conditions are the same as in their model.
} 


\section{$2.4 \quad$ Firms}

\subsubsection{Technology and Profits}

Each firm produces a differentiated good. The production function of the representative US firm is

$$
y_{t}(z)=\ell_{t}(z),
$$

where $y(z)$ is the total output of firm $z$ and $\ell(z)$ is labour input used by firm $z$. For US LCP firms, total output is divided between output sold in the US, $x_{t}(z)$, and output sold abroad, $v_{t}(z)$. Profits are given by

$$
\begin{gathered}
\pi_{t}^{P C P}(z)=p_{t}(z) y_{t}(z)-w_{t} \ell_{t}(z), \\
\pi_{t}^{L C P}(z)=p_{t} x_{t}(z)+E_{t} q_{t}(z) v_{t}(z)-w_{t} \ell_{t}(z), \\
\pi_{t}^{P C P}\left(z^{*}\right)=q_{t}\left(z^{*}\right) y_{t}^{*}\left(z^{*}\right)-w_{t}^{*} \ell_{t}^{*}\left(z^{*}\right), \\
\pi_{t}^{L C P}\left(z^{*}\right)=\left(p_{t}\left(z^{*}\right) v_{t}^{*}\left(z^{*}\right)\right) / E_{t}+q_{t}\left(z^{*}\right) x_{t}^{*}\left(z^{*}\right)-w_{t}^{*} \ell_{t}^{*}\left(z^{*}\right) .
\end{gathered}
$$

Equation (12) shows the profits of a US PCP firm. Equation (13) shows the profits of a US LCP firm. Equations (14) and (15) show the profits of the corresponding European firms.

The demands for the products are given by

$$
\begin{gathered}
y_{t}(z)=\left(\frac{p_{t}(z)}{P_{t}}\right)^{-\theta} n C_{t}+\left(\frac{p_{t}(z)}{E_{t} P_{t}^{*}}\right)^{-\theta}(1-n) C_{t}^{*}, \\
x_{t}(z)=\left(\frac{p_{t}(z)}{P_{t}}\right)^{-\theta} n C_{t}, \\
v_{t}(z)=\left(\frac{q_{t}}{P_{t}^{*}}\right)^{-\theta}(1-n) C_{t}^{*}, \\
y_{t}^{*}\left(z^{*}\right)=\left(\frac{E_{t} q_{t}\left(z^{*}\right)}{P_{t}}\right)^{-\theta} n C_{t}+\left(\frac{q_{t}\left(z^{*}\right)}{P_{t}^{*}}\right)^{-\theta}(1-n) C_{t}^{*}, \\
v_{t}^{*}\left(z^{*}\right)=\left(\frac{p_{t}\left(z^{*}\right)}{P_{t}}\right)^{-\theta} n C_{t}, \\
x_{t}^{*}\left(z^{*}\right)=\left(\frac{q_{t}\left(z^{*}\right)}{P_{t}^{*}}\right)^{-\theta}(1-n) C_{t}^{*} .
\end{gathered}
$$

Equation (16) shows the demand for a US PCP firm. Equations (17) and (18) show the demand for a US LCP firm in the US and European markets, respectively. Corresponding European equations are (19)-(21). 


\subsubsection{Price Setting}

In the absence of nominal rigidities, for example, US LCP firms would maximize $\pi_{t}^{L C P}(z)$ with respect to $p_{t}(z)$ and $q_{t}(z)$. This would imply

$$
p_{t}(z)=E_{t} q_{t}(z)=\frac{\theta}{\theta-1} w_{t} .
$$

This implies that the price of good $z$ a constant markup over marginal cost. Without nominal rigidities, the law of one price holds and good $z$ is sold at the same price in both markets, when expressed in the same currency. US PCP firms maximize $\pi_{t}^{P C P}(z)$ with respect to $p_{t}(z)$. The price of good $z$ is a constant markup over marginal cost.

I now turn to staggered price adjustment. I consider a discrete-time version of a model proposed by Calvo (1983). Each firm resets its prices with a probability $1-\gamma$ in each period, independently of other firms and independently of the time elapsed since the last adjustment. When setting its profit-maximizing price, every firm has to take into account that in every subsequent period there is a probability $0<\gamma<1$ that it will not be able to revise its price setting decision. When setting a new price in period t, each firm seeks to maximize the present value of profits weighting future profits by the probability that the price will still be in effect in that period. For example, the representative US LCP firm seeks to maximize

$$
\max _{p_{t}(z), p_{t}^{*}(z)} V_{t}^{L C P}(z)=\sum_{s=t}^{\infty} \gamma^{s-t} \zeta_{t, s} \pi_{t}^{L C P}(z),
$$

where $\zeta_{s, t}=\Pi_{j=s}^{t}\left(1+i_{j}\right)^{-1}$ is the US nominal discount factor between period $t$ and period $s$. The result is that the pricing rules are given by

$$
\begin{aligned}
& p_{t}(z)=\left(\frac{\theta}{\theta-1}\right) \frac{\sum_{s=t}^{\infty} \gamma^{s-t} \zeta_{t, s} C_{s}\left(\frac{1}{P_{s}}\right)^{-\theta} w_{s}}{\sum_{s=t}^{\infty} \gamma^{s-t} \zeta_{t, s} C_{s}\left(\frac{1}{P_{s}}\right)^{-\theta}}, \\
& q_{t}(z)=\left(\frac{\theta}{\theta-1}\right) \frac{\sum_{s=t}^{\infty} \gamma^{s-t} \zeta_{t, s} C_{s}^{*}\left(\frac{1}{P_{s}^{*}}\right)^{-\theta} w_{s}}{\sum_{s=t}^{\infty} \gamma^{s-t} \zeta_{t, s} C_{s}^{*}\left(\frac{1}{P_{s}^{*}}\right)^{-\theta} E_{s}}
\end{aligned}
$$

Equation (24) demonstrates that US export prices, expressed in euros, do not change when the nominal exchanges rate changes. This implies that exchange rate pass-through to export prices is zero. The pricing rule for a US PCP good is the same as equation (23). This implies that US PCP firms 
let euro prices move one-to-one with the exchange rate, i.e. there is complete exchange rate pass-through to export prices. The corresponding European equations are

$$
\begin{aligned}
& p_{t}\left(z^{*}\right)=\left(\frac{\theta}{\theta-1}\right) \frac{\sum_{s=t}^{\infty} \gamma^{s-t} \zeta_{t, s}^{*} C_{s}\left(\frac{1}{P_{s}}\right)^{-\theta} w_{s}^{*}}{\sum_{s=t}^{\infty} \gamma^{s-t} \zeta_{t, s}^{*} C_{s}\left(\frac{1}{P_{s}}\right)^{-\theta} \frac{1}{E_{s}}} \\
& q_{t}\left(z^{*}\right)=\left(\frac{\theta}{\theta-1}\right) \frac{\sum_{s=t}^{\infty} \gamma^{s-t} \zeta_{t, s}^{*} C_{s}^{*}\left(\frac{1}{P_{s}^{*}}\right)^{-\theta} w_{s}^{*}}{\sum_{s=t}^{\infty} \gamma^{s-t} \zeta_{t, s}^{*} C_{s}^{*}\left(\frac{1}{P_{s}^{*}}\right)^{-\theta}}
\end{aligned}
$$

\subsubsection{Symmetric Equilibrium}

All firms in a country are symmetric and every firm that changes its price in any given period chooses the same output and sets the same price, consistent with equations (23)-(26). The structure of price setting implies that each period a fraction of firms, $1-\gamma$, sets a new price and the remaining fraction keeps their price unchanged.

Equations (10), (13) and (14) can be substituted into (2) to derive the consolidated budget constraint of the US economy. Making use of the global asset-market-clearing condition, the consolidated budget constraint of the European economy can be calculated analogously. The consolidated budget constraints can be written as

$$
\begin{aligned}
\delta_{t} D_{t}=D_{t-1}+(1-b) p_{t}(z) x_{t}(z)+b\left[p_{t}(z) x_{t}(z)+E_{t} q_{t}(z) v(z)\right]-P_{t} C_{t} \\
-\frac{n}{1-n} \delta_{t}^{*} \frac{D_{t}}{E_{t}}=-\frac{n}{1-n} \frac{D_{t-1}}{E_{t}}+\left(1-b^{*}\right) q_{t}\left(z^{*}\right) y_{t}^{*}\left(z^{*}\right) \\
+b^{*}\left[q_{t}\left(z^{*}\right) x_{t}^{*}\left(z^{*}\right)+\frac{p_{t}\left(z^{*}\right) v_{t}^{*}\left(z^{*}\right)}{E_{t}}\right]-P_{t}^{*} C_{t}^{*}
\end{aligned}
$$

The model is log-linearised around a symmetric steady state where all exogenous variables are constants. In addition, I consider the special case where initial net foreign assets are zero. The optimal labour supply (6), the production function (11) and the pricing rule (22) imply that in initial equilibrium

$$
\bar{y}_{0}=\bar{\ell}_{0}=\left(\frac{\theta-1}{\theta}\right)^{\frac{1}{2}},
$$

where the subscript zero on barred variables denotes the initial steady state. The log-linearisation is implemented by expressing the model in terms of 
percentage deviations from the initial steady state. Those variables whose initial steady state value is zero are normalized by consumption. Equilibrium is sequences of variables that (i) clear the labour, goods and money markets in each region in each period, (ii) satisfy the optimality conditions for consumption evolution, (iii) satisfy the optimal pricing rules and (iv) satisfy the intertemporal budget constraints.

\section{The International Transmission of Mone- tary Shocks}

In this section, I analyse the international effects of monetary shocks, using illustrative numerical simulations. First, I briefly discuss the parameterisation of the model. The main point of this paper is to analyse the international transmission of monetary policy under DP and to compare these results with those of Obstfeld and Rogoff $(1995,1996)$ and Betts and Devereux (2000). The model, however, extends the basic framework in two ways: by the introduction of staggered price setting and asymmetric pricing. Thus the differences in the results could be coming partly from the currency choice of pricing and partly from the staggered pricing mechanism itself. I therefore first discuss the international transmission of monetary shocks under symmetric pricing i.e. under PCP and LCP. This section shows how staggered price setting affects the results of Obstfeld and Rogoff $(1995,1996)$ and Betts and Devereux (2000). These results allow for distinguishing the consequences of asymmetric pricing with those of staggered price setting. The next step is to discuss the international effects of monetary shocks under DP. In this section, I also implement a sensitivity analysis to study to what extent the international effects of monetary shocks may be sensitive to the choice of some key parameter values.

\subsection{Parameterisation}

The parameterisation of the model mostly follows Schmidt (2006), making it easy to compare the results of this model with those of Schmidt (2006). Periods are interpreted as quarters. The discount factor $\beta$ is set to 0.99 , which implies a 4 percent annual real interest rate. The price stickiness parameter $\gamma$ is set to 0.75 , implying an average delay between price adjustments of four periods (one year). The parameter $\chi$ is set to 1 . The two countries are assumed to be of equal size, i.e. $n=0.5$. The consumption elasticity of money demand $(1 / \varepsilon)$ is set to 1 . 
In this model, unlike in Schmidt (2006), the same parameter $(\theta)$ governs the elasticity of substitution between two goods produced in the same country and the elasticity of substitution between two goods produced in different countries. Schmidt (2006) set the former elasticity to 10 and the elasticity of substitution between domestic and foreign goods to 1.5. Obstfeld and Rogoff (2000a, Section 2.3) briefly survey the literature on empirical estimates of the elasticity of substitution between domestic and foreign goods. They quote estimates in the range of 1.2 to 21.4. Typical estimates, however, are in the range of 5 to 6 . I set $\theta$ to 6 . This parameter value is widely used in the related literature, as e.g., in Sutherland (1996). I simulate the model using the algorithm developed by Klein (2000) and McCallum (2001).

\subsection{Simulation Results: Symmetric Pricing}

In this section, I study the international transmission of a US monetary shock under both PCP and LCP. Consider the Dornbusch exercise of an unanticipated permanent rise in the relative US money supply. Figure 1 (on Page 29) shows the dynamic responses of key macroeconomic variables to 1 percent rise in the US money supply. In all figures, the vertical axes show percentage deviations from the initial steady state. The change in bond holdings is, however, expressed as a deviation from initial consumption. Panels (a) through (f) depict the effects of a monetary shock under PCP, and panels (g) through (l) show the effects of the same shock under LCP. The real exchange rate is

$$
\text { Real exchange rate }=\frac{E_{t} P_{t}^{*}}{P_{t}} .
$$

The US terms of trade are (defined as) the (Calvo-weighted) relative price of US exports in terms of US imports. Thus the US terms of trade improve if this index rises.

The welfare analysis of monetary policy is somewhat more complicated than in the basic NOEM models. Typically in the NOEM literature all prices are fixed for one period and the new steady state is reached after one period. In this framework, the welfare effect of a monetary shock is the sum of the short run change in utility and the discounted present value of the change in steady state utility. Because of the staggered price setting, I use a different method to evaluate welfare changes. First, I study changes in one period's utility. Then I calculate the discounted present value of the change in utility. ${ }^{8}$

\footnotetext{
${ }^{8}$ For instance, in Schmidt (2006): "[w]elfare effects were derived as the discounted sum of all future utility changes compared to the steady-state path of utility."
} 
The change in utility in period $t$ is given $b^{9}$

$$
\hat{U}_{t}=\hat{C}_{t}-\bar{\ell}_{0}^{2} \hat{\ell}_{t}
$$

The discounted present value of the change in utility is

$$
\hat{U}_{D P V}=\sum_{s=t}^{\infty} \beta^{s-t} \hat{U}_{s} .
$$

Figure 1 illustrates the changes in period's utility. Table 1 shows the changes in period utility in the 1st and 20th period and the discounted present value of the change in utility.

Table 1: Welfare Effects of Monetary Shocks

\begin{tabular}{|c|c|c|c|c|c|c|}
\hline & $\hat{U}_{1}$ & $\hat{U}_{1}^{*}$ & $\hat{U}_{20}$ & $\hat{U}_{20}^{*}$ & $\hat{U}_{D P V}$ & $\hat{U}_{D P V}^{*}$ \\
\hline PCP & -1.1 & 1.2 & 0.022 & -0.022 & 0.16 & 0.16 \\
\hline LCP & 0.43 & -0.32 & 0 & 0 & 1.6 & -1.3 \\
\hline DP - US shock & -0.31 & 0.47 & 0.12 & -0.12 & 0.97 & -0.48 \\
\hline DP - European shock & 0.42 & -0.36 & -0.12 & 0.12 & -0.64 & 0.81 \\
\hline
\end{tabular}

\subsubsection{Producer Currency Pricing}

In the PCP case, the model is virtually identical to that of Obstfeld and Rogoff $(1995,1996)$ and completely identical to Betts and Devereux (2000) in the special case of their model where all firms set their prices in the consumers' currency, expect for the extra dynamics introduced by the staggered price setting. Panel (a) through (e) show that the positive (as opposed to the normative) effects of a monetary shock are almost identical to those of Obstfeld and Rogoff $(1995,1996)$ and Betts and Devereux (2000). The only exception is that, because a fraction of firms can adjust their prices immediately after the shock, the short run change in the terms of trade is smaller than the change in the exchange rate. However, the manner in which the welfare effects of monetary shocks are analysed highlights some important perspectives. Since the PCP case is known in the NOEM literature, I discuss only the effects of a monetary shock that are vital in understanding welfare results.

A monetary expansion lowers the real interest rate and thus raises global consumption demand. A monetary shock depreciates the nominal exchange rate which raises the relative prices of European goods, shifting global demand toward US goods away from European goods. ${ }^{10}$ This expenditure

\footnotetext{
${ }^{9}$ As typical in the literature, I neglect the utility derived from real balances.

${ }^{10}$ Because preferences are identical across regions and the law of one price holds for all goods, the CPI-based real exchange rate is always constant.
} 
switching effect of a nominal exchange rate change increases US output and decreases European output as long as prices are sticky, as shown in Figure 1, panel (a). The depreciation of the dollar therefore also causes a short run increase in relative US consumption. To smooth consumption, US households save part of this extra income by running a current account surplus (see panel (e) in Figure 1). With higher long run wealth, US households choose to decrease their labour supply, consequently decreasing US output in the long run. A fall in the supply of US goods causes a deterioration of US terms of trade. These effects are, however, relatively weak: US output decreases by just less than 0.01 percent and the terms of trade deteriorate by just less than 0.05 percent in the long run.

Panel (b) of Figure 1 illustrates that a shock also increases consumption in Europe. In the short run, the depreciation of the dollar increases the dollar price of imports but leaves export prices unaffected. Consequently, the US terms of trade deteriorate in the short run. The improvement in the European terms of trade and the fall in the interest rate lead to an increase in European consumption.

One of the main results of Obstfeld and Rogoff $(1995,1996)$ is that a monetary shock increases US (domestic) and European (foreign) overall utility by the same amount, despite asymmetric output effects. This appears to also be the case in this model: the discounted present value of the change in utility is 0.16 in both countries. ${ }^{11}$ The liquidity effect of monetary policy increases world output, bringing it closer to its efficient level and consequently increasing overall welfare in both countries.

Panel (f), however, illustrates that the asymmetric output effects of monetary policy do have important implications for welfare in the short run. In the short run, US consumption increases less than proportionally to output due to the deterioration in the US terms of trade and the accumulation of external assets. Therefore, a monetary expansion is a "beggar-thyself" policy in the short run. In the long run, the short run US current account surplus implies a permanent US trade balance deficit which allows consumption to remain above US output. This trade balance deficit and the improvement in the US terms of trade have a positive effect on long run consumption and

\footnotetext{
${ }^{11}$ In the Obstfeld and Rogoff (1995) model, the overall welfare effect of a monetary shock is $\hat{U}_{\text {Overall }}=\hat{U}_{\text {Overall }}^{*}=\frac{\beta+\varepsilon(1-\beta)}{\theta}\left[n \hat{M}+(1-n) \hat{M}^{*}\right]$. Using the same parameters values as in the present model, the previous equation implies that a monetary shock increases domestic and foreign utility by 0.083 percent in the Obstfeld and Rogoff (1995) model. This amounts to approximately half of the welfare gain of this model. Why? In the present model, the parameter value chosen for staggered pricing implies an average delay of four periods for pricing adjustment while Obstfeld and Rogoff (1995) have prices that are sticky for one period. This implies a stronger liquidity effect of monetary policy in this model.
} 
consequently on welfare. In addition, a fall in labour supply increases steady state utility. Thus US utility increases by 0.022 percent in the long run.

A US shock increases European welfare in the short run because of an increase in consumption and a fall in employment (output). The international welfare spillover is reversed in the long run, due to the changes in the patterns of European consumption and employment. With lower wealth, European households choose to work more and output increases in the long run. This reduces welfare but also causes an increase in the supply of European goods and therefore a deterioration of the European terms of trade. In addition, to service the debt, Europe must run a trade balance surplus. This trade balance surplus and the deterioration in the terms of trade have a negative effect on consumption and thus on welfare. In the long run, European utility decreases by 0.022 percent.

The analysis of this section shows that even though the terms of trade and current effects of monetary policy do not affect overall welfare, they still have significant consequences for welfare both in the short and long run. The two countries gain in equal measure from the overall utility changes. The liquidity effect of monetary policy increases world output closer to its efficient level and increases global welfare in the short run. In the short run, the welfare gains of European households are higher than the welfare losses of US households. In Europe, the short run welfare benefits from higher consumption and lower labour supply dominates the long run welfare losses from lower consumption and higher labour supply. In the case of the US, the long run welfare benefits from higher consumption and lower labour supply dominates short run welfare losses. Thus both countries benefit from a US monetary expansion.

\subsubsection{Local Currency Pricing}

Panels (g) through (l) in Figure 1 show that under LCP the introduction of a staggered price setting into the Betts and Devereux (2000) model changes the main results of their paper only slightly. ${ }^{12}$ The nominal and real exchange rate are not perfectly correlated in the short run because a fraction of firms can adjust their prices immediately after the shock. For the same reason, the change in the terms of trade is smaller that the movement in the nominal exchange rate. Figure 1 highlights the main finding of Betts and Devereux

\footnotetext{
${ }^{12}$ Pierdzioch (2003) extends the model of Betts and Deverueux (2000) by the introduction of the Calvo price setting framework. He analyses the positive effects of monetary shocks in the presence of full LCP. Thus, the model of this paper, in the LCP case, replicates the results of Pierdzioch (2003). In addition, I also analyse the welfare effects of monetary shocks.
} 
(2000): The international effects of monetary shocks are sensitive to the pricing of exports. Panel (g) shows that outputs are perfectly positively correlated. Panel (l) demonstrates that a monetary expansion under LCP is a "beggar-thy-neighbour" policy that raises US welfare and reduces European welfare, consistent with Betts and Devereux (2000).

The impact on output is primarily determined by the direct demand increase by US households'. With no exchange rate pass-through, this direct demand increase is identical for both US and European goods, and output increases by the same amount in both countries. When US firms price their exports in dollars, the exchange rate depreciation increases their profits measured in dollars. It also reduces the profits of European firms measured in euros. The dollar's depreciation thus generates a change in the distribution of income favouring the US, increasing US consumption and decreasing European consumption. Since a monetary shock does not generate short run current account imbalances, monetary policy is neutral in the long run. The impact on output is determined primarily by the direct demand increase coming from US households. With no exchange rate pass-through, this direct demand increase is identical for both US and European goods, and output increases by the same amount in the both countries. When US firms price their exports in dollars, the dollar's depreciation increases their profits measured in dollars. On the other hand, it reduces the profits of European firms measured in euros. The dollar's depreciation thus generates a distribution of income toward the US, increasing US consumption and reducing European consumption. Since a monetary shock does not generate short run current account imbalances, monetary policy is neutral in the long run.

A US monetary expansion raises US welfare in the short run. The positive effect of the resulting higher consumption is larger than the negative effect resulting from higher employment (output). A US monetary expansion, however, reduces European welfare. The reason behind this result is that a US monetary shock reduces European consumption due to the deterioration of European terms of trade. The discounted present value of the change in utility in the US is 1.6 and in Europe -1.3.

The results of this section highlight the consequences of the introduction of a staggered price setting into the basic NOEM framework. These results give us a good benchmark to evaluate how DP itself affects the international transmission of monetary policy. As shown in this section, the Calvo-pricing mechanism does not change the main predictions of the basic NOEM models. 


\subsection{Simulation Results: Dollar Pricing}

\subsubsection{US Monetary Shocks}

Figure 2 (Panels (a) through (f)) demonstrates the macroeconomic effects of a US shock under DP and under the baseline calibration. It shows that a US shock generates a negative co-movement of output and a positive comovement of consumption across countries. Panel (f) illustrates that a shock reduces US welfare but raises European welfare in the short run. In comparison to the PCP and the LCP cases, the dynamic effects of a monetary shock under DP appear to be more similar to PCP than LCP. Table 1 illustrates that a US monetary shock is a beggar-thy-neighbour policy.

A monetary shock temporarily lowers the real interest rate and raises global consumption demand. The rise in global demand has differing effects on US and European output, because of the exchange rate change. In the DP case, exchange rate pass-through is asymmetric: It is zero in the US and one in Europe. In Europe, with sticky prices, the depreciation of the dollar implies that European goods become more expensive relative to US goods. European households substitute consumption towards US goods and away from European goods. The strength of this expenditure switching effect depends on the elasticity of substitution between domestic and foreign goods. The expenditure switching effect causes an increase in US income and thus a rise in relative US consumption. As panel (e) shows, to smooth consumption, US households save part of this income by running a current account surplus.

In case of sticky prices in the US, the relative price of US to European goods is unaffected. The impact of a monetary shock on the output of the two countries is influenced by the direct demand increase by US households. This direct demand increase is identical for both US and European goods. The effect is dominated by the expenditure switching effect: European output falls in the first period. However, the direct demand increase implies than European output rises by almost 0.1 percent in the medium run.

Panel (c) displays that the depreciation of the dollar is smaller than the relative increase in the money supply, as in Obstfeld and Rogoff (1995). A US monetary shock generates a short run current account surplus which entails a permanent rise in relative US consumption. This mitigates the depreciation of the dollar and the dollar depreciates by 0.99 percent. In the DP case, as in the LCP case (Betts and Devereux 2000), the exchange rate overshoots if the consumption elasticity of money demand is less than one $(\varepsilon>1)$. Panel (c) also demonstrates that the nominal depreciation translates into a real depreciation.

A US monetary shock increases European consumption in the short run. 
A decrease in European output reduces income in the short run. In addition, the depreciation of the dollar affects the earnings of European firms. When European firms price their exports in dollars, the depreciation of the dollar reduces their earnings measured in euro terms. This reduces European consumption. This effect is, however, dominated by other, positive effects. The exchange rate depreciation induces a fall in the European CPI allowing for an increase in consumption in the short run. In addition, European household increase their consumption by running a current account deficit. In the long run, the accumulation of external debt and a deterioration of European terms of trade imply that European consumption falls in real terms. This effect, however, is very weak: European consumption falls by just less than 0.01 percent.

A closer look at Panel (b) of Figure 2 reveals that US consumption increases in the long run by just more than 0.01 percent. The accumulation of external assets and the improvement in the US terms of trade have a positive effect on long run US consumption. US households, with higher long-run wealth, choose to work less (the opposite happens in Europe). A fall in the supply of US goods raises their relative price.

Panel (d) in Figure 2 illustrates that the US terms of trade improve, despite the fact that both US exports and imports are set in dollars. In the short run, a fraction of firms sets new prices and an outward shift in the demand curve facing the US firms allows them to raise their prices. Therefore the US terms of trade also improve in the short run.

Table 2 shows that the overall welfare effect of a US monetary shock is positive on US welfare and negative on European welfare. This is consistent with Schmidt (2006) who only analyses the overall welfare effect of a monetary shock, however. Comparing the Obstfeld and Rogoff setup of PCP and the Betts and Devereux setup of LCP with the present model, I find that the overall welfare effect of a monetary shock under DP is similar to LCP. A US monetary shock increases US welfare at the expense of Europe by adversely affecting European terms of trade, as in the LCP case. The channel through which a US shock deteriorates the European terms of trade is, however, different. Under DP, it is optimal for US firms to raise their prices due to higher demand and therefore the US terms of trade improve in the short run. Under LCP, the depreciation of the dollar improves the US terms of trade in the short run. Since US terms of trade improve by less under DP in the case of LCP, a US monetary shock increases US overall welfare by less than in the case of LCP.

Panel (f) of Figure 2 illustrates the response of US and European period utility to a monetary expansion. In the short run, a US monetary shock reduces US welfare but increases welfare in Europe. In this respect, the short 
run welfare effects are more similar to PCP, notwithstanding the improvement in the US terms of trade. As mentioned, US households are willing to lend resources abroad for consumption smoothing purposes. This current account effect dominates the terms of trade effect. As a result, the increase in consumption is much smaller than the increase in output in the first period after the shock. US welfare is therefore reduced in the short run. The DP case reintroduces the current account as an important channel through which monetary policy affects welfare in the short run. Even though the current account effect does not affect overall welfare, it has important implications for welfare dynamics.

In the long run, the external wealth implies a fall in labour supply and a permanent US trade balance deficit which allows consumption to remain above US output. In addition, the improvement in the US terms of trade has a positive effect on consumption and consequently on welfare. As mentioned, Table 1 shows that a US monetary shock increases US overall welfare as the improved terms of trade and higher wealth allow US households to finance higher real consumption at a lower level of labour supply in the long run.

\section{Sensitivity Analysis}

One of the main findings of Schmidt (2006) is that DP provides a better fit to some stylized facts than other pricing schemes (PCP or LCP). Several empirical papers have shown that US monetary policy has a positive effect on the output of the rest of the world. For example, Betts and Devereux (2001) and Kim (2001) find that U.S. monetary shocks have a positive economic impact on non-US G7 countries. Holman and Neumann (2002) find that US monetary shocks have a positive effect on both Canadian output and consumption. Schmidt (2006) finds that asymmetric exchange rate pass-through implies that a monetary shock causes positive cross country correlations in both output and consumption. This is not, however, the outcome of these computations.

The above discussion suggests that the effect of a monetary shock on European output may be sensitive to the parameters that govern the strength of the expenditure switching effect, e.g. the elasticity of substitution between domestic and foreign goods. The larger the elasticity (high $\theta$ ), the stronger the expenditure switching effect. Panels (g) and (h) of Figure 2 show the effects of a monetary shock on output and consumption in the case where this elasticity is low $(\theta=3)$ but still higher than in Schmidt (2006) in which this elasticity is set to $1.5 .^{13}$

\footnotetext{
${ }^{13}$ Only the effects on output and consumption are shown. The setting of $\theta=3$ has virtually no impact on other variables than outputs. Except for the fact that the welfare
} 
A low elasticity of substitution between domestic and foreign goods implies that the expenditure switching effect is weak in Europe. Thus the direct increase in demand by US households dominates the expenditure switching effect. In addition, European output rises. Thus a monetary shock causes a positive cross country correlation in output. This suggests that the result of Schmidt (2006), which sees a monetary shock under DP generate positive cross country correlations in output and consumption, is not a generally applicable result, but is likely to be dependent on a low "elasticity of trade".

Another important parameter that determines the strength of the expenditure switching effect is the degree of price rigidities. If prices were more flexible, the expenditure switching effect would become weaker and peter out faster. Panels (i) and (j) of Figure 2 illustrate the effects of a monetary shock on output and consumption in the case where the fraction of firms setting a new price in each period is increased to $0.5(\gamma=0.5) .{ }^{14}$

With more flexible prices, the correlation between US and European output becomes positive in the short run as the expenditure switching effect is dominated by the direct demand increase coming from US households. The depreciation of the dollar does not affect the relative price of imports as much as in the previous case. This implies that consumption substitution toward US goods away from European goods becomes weaker in Europe. The direct increase in demand by US households also becomes weaker than before. This effect now more than offsets the expenditure switching effect, however. European output, therefore, increases.

If the expenditure switching effect is relatively weak, asymmetry in export pricing lead to results that conform more closely to the stylized fact that US monetary shocks have a positive effect on both US and European output and consumption. This result may be relevant with regards to the fact that a considerable share of world export pricing is conducted in US dollars. In terms of the correlations of output and consumption across countries, however, the results provide for more risk sharing than is typically shown in the data. The results show that a monetary shock generates a positive co-movement of consumption across countries that is larger than a positive co-movement of output across countries. This is consistent with a number of open economy models. It is inconsistent, however, with empirical evidence (Backus et al. 1992).

effects of the shock are different in the case of $\theta=3$. This is likely to be caused by the fact that this parameter also determines the initial level of output implying that equilibrium output is far below the socially optimal level. Thus any increase in consumption is more likely to be welfare-improving.

${ }^{14}$ The consequences of varying $\gamma$ on the other variables than European output are purely quantitative. 


\subsubsection{European Monetary Shocks}

I now turn to study the macroeconomic effects of a European monetary shock and consider the same unanticipated, permanent rise in the money supply. Figure 3 shows the macroeconomic effects of US and European monetary shocks on output, consumption and welfare. Only these effects are shown because the responses of other variables are analogously to the case of a US shock. The solid lines show the effects of a US monetary shock and the dashed lines show the effects of a European monetary shock. The "country's own output" refers to US (European) output in the case of a US (European) shock and the "other country's output" refers to European (US) output in the case of a US (European) shock.

It is worth observing that the assumption of DP is not the only asymmetry in the model as the nominal bond is denominated in dollars. However, due to the setting of $\varepsilon=1$, nominal interest rates are equalized across countries and thus realized returns on the international bond are also equalized across countries. The real interest rates can diverge across countries due to violations of the law of one price. Thus the international inequality of the interest rates is caused by DP not by the fact that the bond is denominated in dollars.

Figure 2 and Table 1 reveal three noteworthy results. First, a US monetary expansion increases US output and consumption by more than a European expansion increases European output and consumption. Second, while a US monetary shock increases European consumption, a European shock reduces US consumption. Summing up I find that US monetary shocks generate positive co-movements of consumption across countries while European shocks generate negative co-movements. Three, notwithstanding the fact that the origin of the shock has important implications for consumption and output, the welfare effects of monetary shocks are almost identical. Both US and European shocks increase the country's own welfare at the expense of the other country's welfare.

The differences in the international transmission of US and European monetary shocks stem from asymmetric exchange rate pass-through. Both a European monetary shock and a US shock, cause an exchange rate depreciation. In the case of a US shock, the direct increase in demand by US households increases demand for both US and European goods because the depreciation of the dollar does not affect the price of imports to the US. In the case of a European shock, however, the depreciation of the euro raises the price of imports in Europe and European goods become cheaper relative to US goods. The expenditure switching effect raises European output and consumption but tends to reduce US output and consumption. 
A European shock raises European output by less than a US shock raises US output despite the fact that the preceding analysis might suggest the opposite. The intuition behind this result is as follows. As mentioned, in the case of a US shock, the depreciation of the dollar implies an expenditure switching effect in Europe ("the other country"). This causes an increase in US output and consumption. In the case of a European shock, due to DP, the depreciation of the euro does not affect the price of imports in the US ("the other country") and there is no expenditure switching effect in the US. This direct demand increase dominates the expenditure switching effect in that the positive impact of a European monetary shock on European output is smaller than the positive impact on a US monetary shock on US output. Asymmetric expenditure switching effects explain the asymmetric transmission of US and European monetary shocks.

Panel (d) of Figure 3 shows that a European monetary shock decreases US consumption. With no exchange rate pass-through to import prices in the US, the depreciation of the euro does not cause the US CPI to fall. Thus the mechanism that allows for an increase in European consumption following a US shock does not increase US consumption in the case of a European shock. Due to DP, the exchange rate change mainly impacts on the profits of firms. The depreciation of the euro reduces the dollar earning of US firms, which tends to reduce US consumption.

Figure 3 and Table 1 show that the welfare effects of a European monetary shock are, despite the asymmetric transmission of shocks, almost identical to those of a US shock. The only notable difference being that a European shock reduces US consumption (panel $(\mathrm{d})$ ). In this case, the welfare benefit from a lower level of US employment almost perfectly offsets the welfare losses from a lower level of US consumption in that the effect of a European shock on US welfare is almost the same as the effect of a US shock on European welfare.

Finally, it is worth mentioning that the effect of a European monetary shock on US output is not sensitive to the choice of parameter values. The expenditure switching effect in Europe dominates the direct demand increase coming from US households. A European shock decreases US output also in the case of $\theta=3$ or $\gamma=0.5$.

\subsubsection{An Appraisal of the Merits of the DP Model}

It is a challenge for any open economy model to capture some international business-cycle regularities. The stylized facts of international business cycles include the following observations:

- US monetary policy has a positive effect on both US and "European" 
(the non-US G7 countries) output and consumption (e.g. Holman and Neumann 2002).

- Co-movements of output across countries are larger than co-movements of consumption across countries (Backus et al. 1992).

- Nominal and real exchange rates are highly correlated (Mussa 1986).

- The real exchange rate is more volatile than the terms of trade (Mendoza 1995).

- Nominal depreciations are associated with deteriorations of the terms of trade (Obstfeld and Rogoff 2000).

- US monetary policy affects US output more than European monetary policy affects European output (Angeloni et al. 2003).

As shown by Schmidt (2006), the incorporation of DP into the NOEM model leads to results that conform more closely to the first stylized fact than the LCP or PCP models. I show, however, that predictions regarding the comovement of output across countries are sensitive to the choice of some key parameter values. A monetary shock under DP does not necessarily increase both US and European output and consumption. DP is, however, a potential explanation for the first observation.

In terms of the correlations of output and consumption across countries, the results provide for more risk sharing than is shown in the data. Even if a US monetary shock increases European output, the shock generates positive co-movements of consumption that are smaller than the positive comovements of output across countries. In a case in which a monetary shock decreases European output, the DP model appears to provide results that are similar to those of the PCP model: high international consumption correlations relative to output correlations. These correlations are not consistent with empirical evidence. Furthermore, a European shock generates negative correlations of output and consumption across countries.

It is apparent that DP implies a lower correlation between the nominal and real exchange rates than in the case of LCP. As shown by Betts and Devereux (2000), in the basic NOEM framework, where preferences are identical across regions, the correlation between nominal and real exchange rates depends on the degree of LCP. Since DP is based on partial LCP, the LCP model does a better job in terms of nominal and real exchange rates being highly correlated in the short run.

If volatility is measured by the impact effect of a shock, DP can be one reason why the US real exchange rate is more volatile than the US terms of 
trade. There are relatively few models that can explain this phenomenon. If all goods are traded, it is a common result that the volatility of the real exchange rate is proportional to that of the terms of trade (as in the LCP version of this model). In the $\mathrm{DP}$ case, exchange rate movements do not affect the US terms of trade because both import and export prices are set in dollars. However, exchange rate movements affect the real exchange rate to the extent that prices are sticky and set in the consumers' currency. For these reasons, the terms of trade are less volatile than the real exchange rate.

The DP model (as well as the LCP model) predicts that a currency depreciation is associated with an improvement in the country's terms of trade. This is inconsistent with the empirical evidence showing that currency depreciations are associated with deteriorations rather than improvements of the terms of trade (Obstfeld and Rogoff 2000). Only the PCP model is consistent with this observation.

Dollar pricing can explain the observed asymmetry in the effectiveness of US and European monetary policies. In an empirical paper Angeloni et al. (2003) study the transmission of US and European monetary policy. Using large-scale "structural" macro-econometrics models, the authors find that a one percentage point increase in the US short-term interest rate has a substantially stronger negative effect on US output than a one percentage point increase in the Eurozone's interest rate has on the Eurozone's output. This implies that US monetary policy is more effective in influencing output than European monetary policy. The standard explanation for this asymmetry is summarized by de Grauwe and Costa Storti (2005, 2): "A consensus seems to have emerged that because of the existence of labour market rigidities, monetary policies in the Eurozone are less effective in influencing output than is the case in the US." In this paper, I show that under DP European monetary policy affects European output and consumption by less than US monetary policy affects US output and consumption. Asymmetric export pricing can be one reason for the relative effectiveness of US monetary policy. This result may be relevant in that considerable export pricing is conducted in dollars.

\section{Conclusions}

The main point of this paper is to analyse the international transmission of monetary policy in the case where all export prices are set in US dollars. I show that asymmetric exchange rate pass-through implies that the international effects of US monetary shocks are different to those of European shocks. For example, DP can explain the asymmetry in the effectiveness of monetary policy. In the case of DP, US monetary policy has a stronger effect 
on US output than European policy has on European output. I also show that under DP expansionary monetary policy is a beggar-thy-neighbour policy. It increases the country's own overall welfare at the expense of the other country.

Consistent with Schmidt (2006), I find that DP can more accurately explain the positive transmission of US monetary shocks to Europe (i.e. that a US monetary shock has a positive effect on both US and European output and consumption). The DP model can provide a better fit with this stylized fact than other pricing schemes (PCP or LCP). I show, however, that the sign of the change in European output is sensitive to the choice of parameter values.

Modelling suggests that the DP model provides a closer fit to some of the stylized facts. It is, however, weaker than the LCP model at projecting changes in consumption patterns and changes in output correlations across countries. The LCP model, however, predicts that the correlation between US and European consumption is negative. This prediction is inconsistent with empirical evidence. It is a challenge for NOEM models to provide for the observation that co-movements of output and consumption across countries are positive and that outputs are correlated to a higher degree than consumptions. A great deal of work remains to be done in explaining international business-cycle regularities. 


\section{References}

Angeloni, I. - Kashyap, A.K. - Mojon, B. - Terlizzese, D. (2003): The Output Composition Puzzle: A Difference in the Monetary Transmission Mechanism in the Euro Area and U.S.. Journal of Money, Credit and Banking 35, 12651306.

Backus, D.K. - Kehoe, P.J., - Kydland, F.E. (1992). International Real Business Cycles. Journal of Political Economy 100, 745-775.

Betts, C. - Devereux, M. (1996): The Exchange Rate in a Model of Pricing to Market. European Economic Review 40, 1007-1021.

Betts, C. - Devereux, M. (2000): Exchange Rate Dynamics in a Model of Pricing-to-Market. Journal of International Economics 50, 215-244.

Betts, C. - Devereux, M. (2001): The International Effects of Monetary and Fiscal Policy in a Two-Country Model. In Calvo, G. -Dornbusch, R. Obstfeld, M. (eds.) Money, Capital Mobility and Trade: Essays in Honor of Robert Mundell. MIT Press, Cambridge.

Calvo, G. (1983): Staggered Prices in a Utility Maximizing Framework. Journal of Monetary Economics 12, 383-398.

Corsetti, G. - Pesenti, P. (2001): Welfare and Macroeconomic Interdependence. Quarterly Journal of Economics 116, 421-455.

Corsetti, G. - Pesenti, P. (2005): The Simple Geometry of Transmission and Stabilization in Closed and Open Economy. Federal Reserve Bank of New York Staff Report 209.

De Grauwe, P. - Costa Storti, C. (2005): Is Monetary Policy in the Eurozone less effective than in the US? CESifo Working Paper 1606.

Devereux, M. - Engel, C. - Tille, C. (2003): Exchange Rate Pass-Through and the Welfare Effects of the Euro. International Economic Review 44, $223-242$.

Devereux, M. - Shib, K. - Xuc, J. (2007): Global Monetary Policy under a Dollar Standard. Journal of International Economics 71, 113-132. 
Dornbusch, R. (1976): Expectations and Exchange Rate Dynamics. Journal of Political Economy 84, 1161-1176.

ECU Institute (1995): International Currency Competition and the Future Role of the Single European Currency. Kluwer Law International, London.

Engel, C. (2002): Expenditure Switching and Exchange-Rate Policy. In Gertler, M. - Rogoff, K. (eds.) NBER Macroeconomics Annual 2002. MIT Press, Cambridge.

Goldberg, L. - Tille, C. (2005): Vehicle Currency Use in International Trade. NBER Working Paper No. 11127.

Holman, J. A. - Neumann, R. M. (2002): Evidence on the Cross-Country Transmission of Monetary Shocks. Applied Economics 34, 1837-1857.

Kim, S. (2001): International Transmission of U.S. Monetary Policy Shocks: Evidence from VAR's. Journal of Monetary Economics 48, 339-372.

Klein, P. (2000): Using the Generalized Schur Form to Solve a Multivariate Linear Rational Expectations Model. Journal of Economic Dynamics \& Control 24, 1405-1423.

Lane, P. (2001): The New Open Economy Macroeconomics: A Survey. Journal of International Economics 54, 235-266.

Lane, P. - Ganelli, G. (2003): Dynamic General Equilibrium Analysis: The Open Economy Dimension. In Altug, S. - Chanda, J. - Nolan, C. (eds.) Dynamic Macroeconomic Analysis. Cambridge University Press, Cambridge.

Mark, N. (2001): International Macroeconomics and Finance: Theory and Econometric Methods. Blackwell Publishing.

Mendoza, E. (1995): The Terms of Trade, the Real Exchange Rate, and Economic Fluctuations. International Economic Review 36, 101-137.

McCallum, B. (2001): Software for RE Analysis. Computer software available at http://wpweb2.tepper.cmu.edu/faculty/mccallum/research.html

Mussa, M. (1986): Nominal Exchange Rate Regimes and the Behavior of Real Exchange Rates: Evidence and Implications. Carnegie-Rochester Se- 
ries on Public Policy 25, 117-214.

Obstfeld, M. (2002): Exchange Rates and Adjustment: Perspectives from the New Open Economy Macroeconomics. Monetary and Economic Studies 20, 23-46.

Obstfeld, M. - Rogoff, K. (1995): Exchange Rate Dynamics Redux. Journal of Political Economy 103, 624-660.

Obstfeld, M. - Rogoff, K. (1996): Foundations of International Macroeconomics. MIT Press, Cambridge.

Obstfeld, M. - Rogoff, K. (2000a): New Directions for Stochastic Open Economy Models. Journal of International Economics 50, 117-153.

Obstfeld, M. - Rogoff, K. (2000b): The Six Major Puzzles in International Finance: Is There a Common Cause?. NBER Macroeconomics Annual 15, $341-390$.

Schmidt, C. (2006): International Transmission Effects of Monetary Policy Shocks: Can Asymmetric Price Setting Explain the Stylized Facts? International Journal of Finance and Economics 11, 205-218.

Sutherland, A. (1996): Financial Market Integration and Macroeconomic Volatility. Scandinavian Journal of Economics 98, 521-539.

Tavlas, G. (1997): The International Use of the US Dollar: An Optimum Currency Area Perspective. World Economy 20, 730-747. 
Figure 1: Dynamic Effects of US Monetary Shocks under Symmetric Pricing

(a) Output - PCP

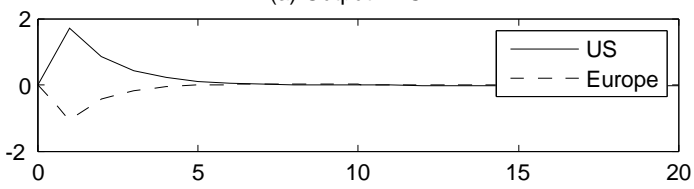

(c) Exchange rate - PCP

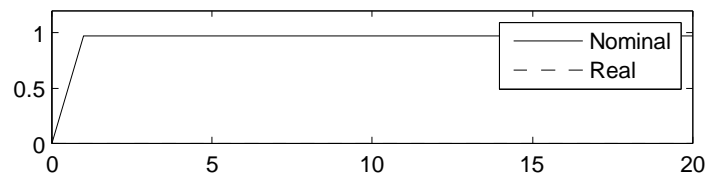

(e) Bond holdings of US households - PCP

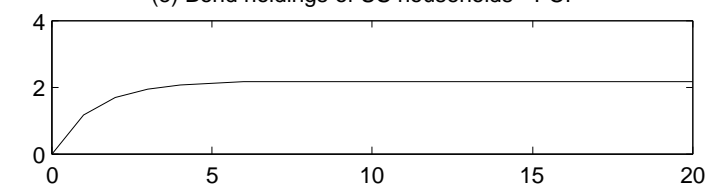

(g) Output - LCP

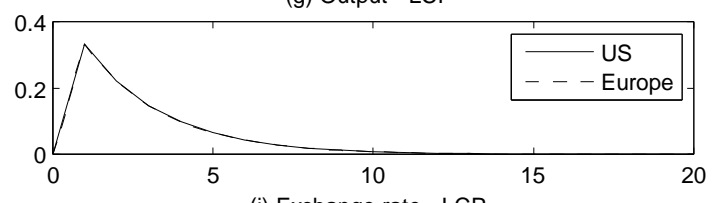

(i) Exchange rate - LCP

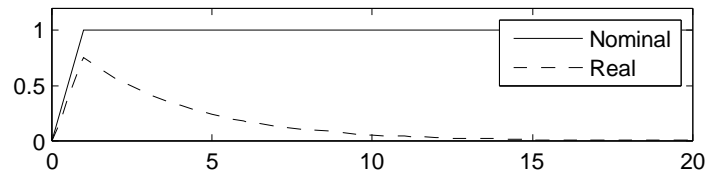

(k) Bond holdings of US households - LCP

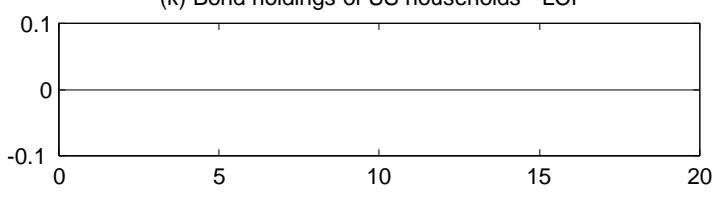

(b) Consumption - PCP

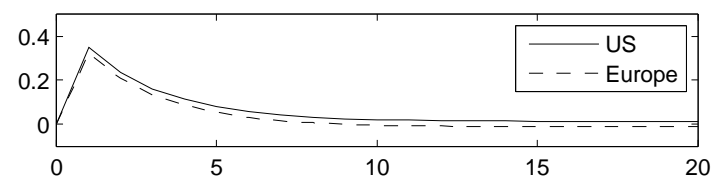

(d) US terms of trade - PCP

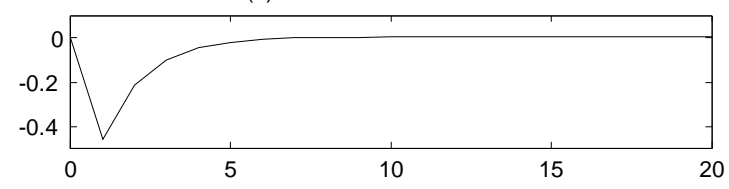

(f) Welfare - PCP

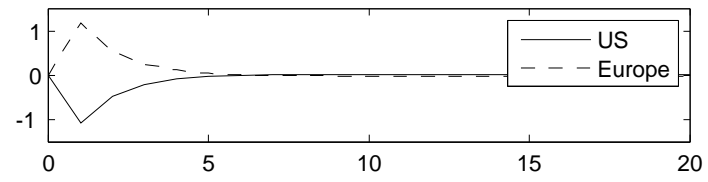

(h) Consumption - LCP
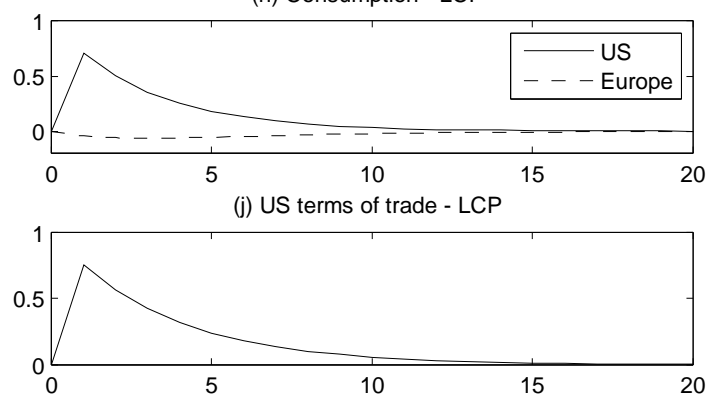

(I) Welfare - LCP

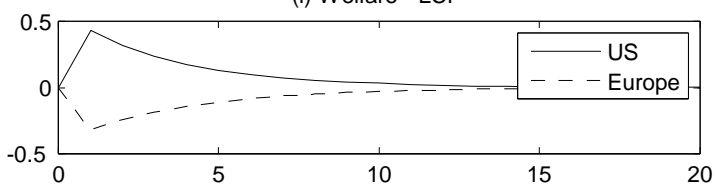


Figure 2: Dynamics Effects of US Monetary Shocks under Dollar Pricing

(a) Output - DP

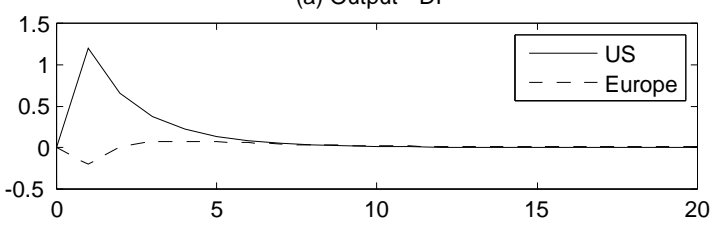

(c) Exchange rate - DP

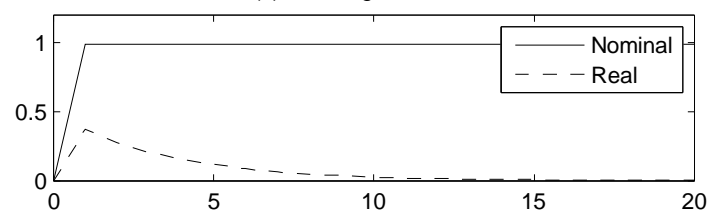

(e) Bond holdings of US households - DP

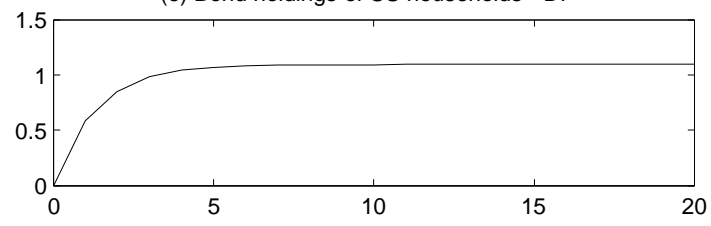

(g) Output - DP, $\theta=3$

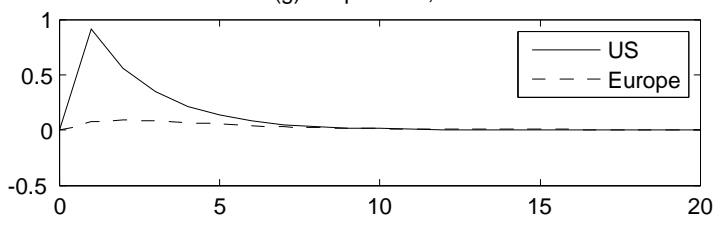

(i) Output - DP, $\gamma=0.5, \theta=6$

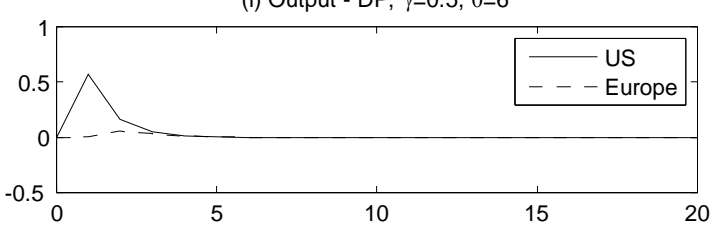

(b) Consumption - DP

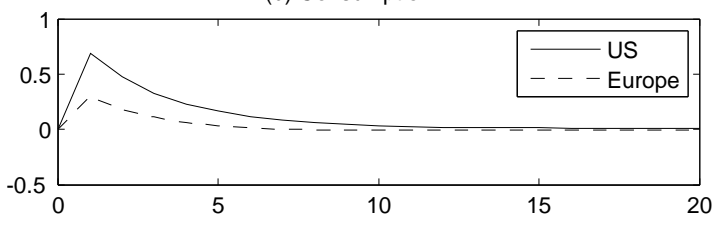

(d) US terms of trade - DP

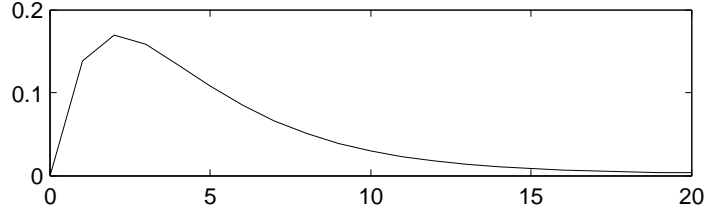

(f) Welfare - DP

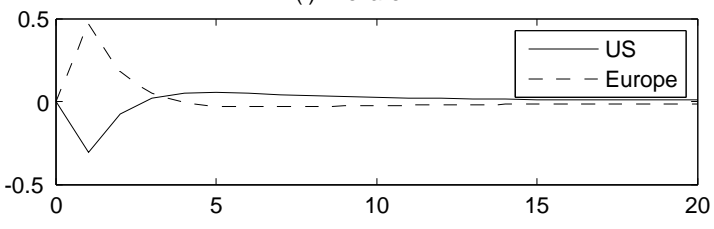

(h) Consumption - DP, $\theta=3$

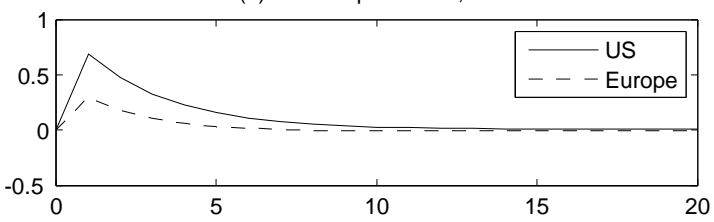

(j) Consumption - DP, $\gamma=0.5, \theta=6$

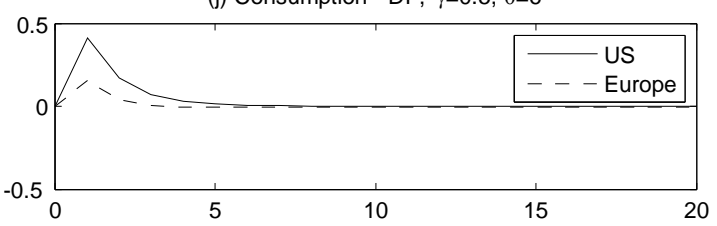


Figure 3: Dynamic Effects of US and European Monetary Shocks under Dollar Pricing
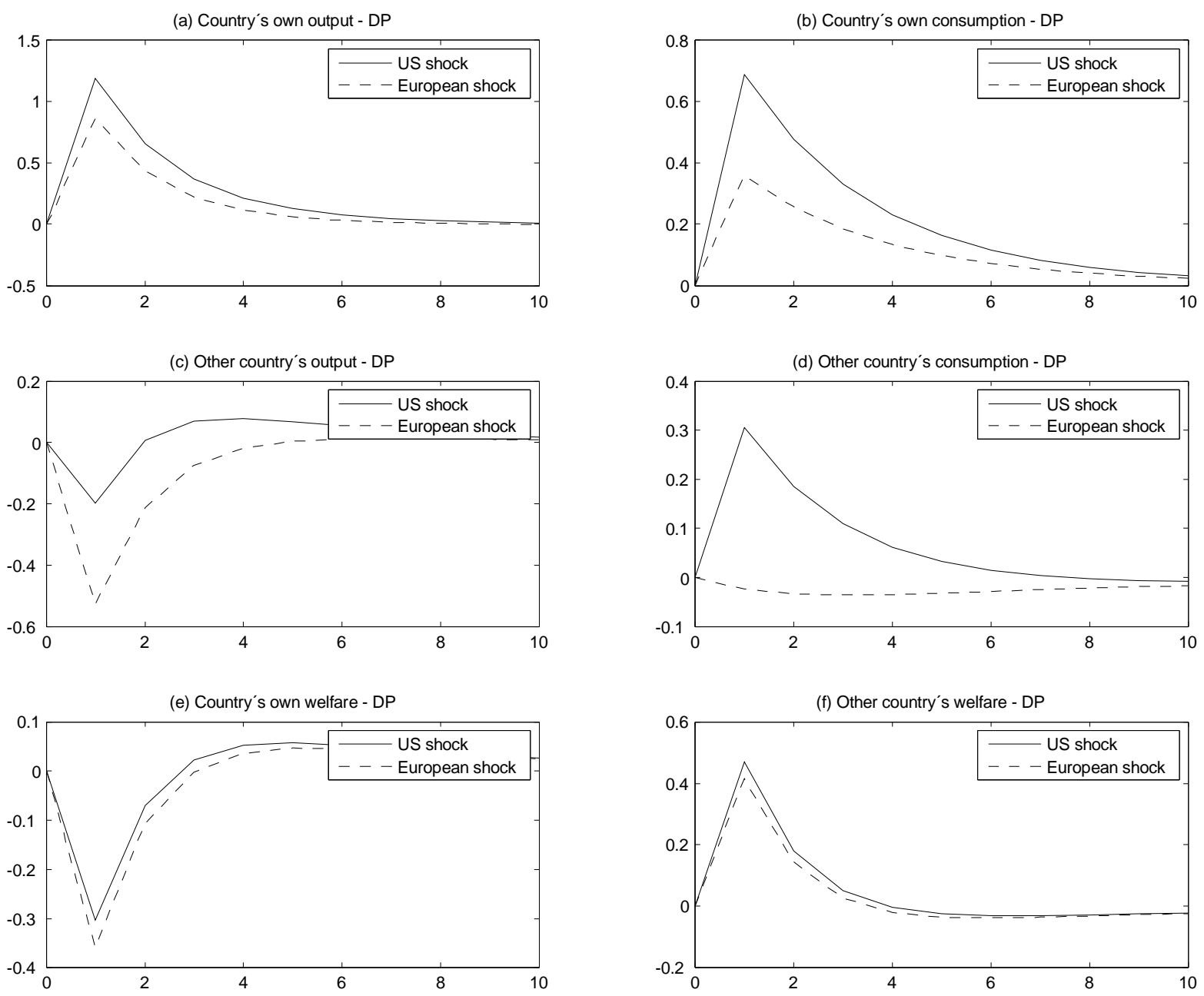